\title{
ANALISIS KEPALA MADRASAH SEBAGAI SUPERVISOR DI LEMBAGA PENDIDIKAN ISLAM
}

\author{
Tio Ari Laksono ${ }^{1}$ \\ ${ }^{1}$ Pascasarjana IAIN Tulungagung, Jawa Timur, Indonesia \\ e-mail: dilandalarva3@gmail.com
}

DOI: 10.35719/leaderia.v2i1.57

\begin{abstract}
This study discusses the managerial aspects of madrasah principals in supervising the preparation, implementation, and follow-up of learning carried out by teachers and madrasah personnel. The method of collecting data in this research is carried out through library research. The responsibilities of the madrasah principal as a supervisor in academic supervision activities include planning, implementation, and evaluation as well as follow-up. Academic supervision activities are carried out to improve the professional quality of teachers and all madrasah personnel. The techniques used in carrying out supervision by the head of the madrasah of teachers and madrasah employees can be done by using individual techniques and group techniques. Activities that include individual techniques are conducting class visits and individual observations, while group techniques include holding meetings or meetings with teachers to discuss various matters related to the teaching and learning process and outcomes.
\end{abstract}

Keywords: Principal of Madrasah, Supervisor, Supervision

\begin{abstract}
ABSTRAK
Penelitian ini membahas mengenai manajerial kepala madrasah dalam melakukan supervisi/pengawasan terhadap persiapan, pelaksanaan dan tindak lanjut pembelajaran yang dilaksanakan oleh guru dan para personalia madrasah. Metode pengumpulan data pada penelitian ini dilakukan melalui studi pustaka (Library Research). Tanggung jawab kepala madrasah sebagai supervisor dalam kegiatan supervisi akademik meliputi perencanaan, pelaksanaan, dan evaluasi serta tindak lanjut. Kegiatan supervisi akademik dilakukan untuk meningkatkan kualitas keprofesionalan guru dan seluruh personalia madrasah. Teknik yang digunakan dalam melaksanakan supervisi oleh kepala madrasah terhadap guru-guru dan pegawai madrasah dapat dilakukan dengan teknik perseorangan dan teknik kelompok. Kegiatan yang termasuk teknik perseorangan adalah mengadakan kunjungan kelas dan observasi perseorangan, sedangkan yang termasuk teknik kelompok adalah mengadakan pertemuan atau rapat dengan guru-guru untuk membicarakan berbagai hal yang berhubungan dengan proses dan hasil belajar mengajar.
\end{abstract}

Kata Kunci: Kepala Madrasah, Supervisor, Supervisi 


\section{PENDAHULUAN}

Pendidikan adalah usaha sadar yang dirancang dan dilakukan dengan sengaja untuk mencapai tujuan yang telah ditetapkan. Pendidikan bertujuan untuk meningkatkan kualitas sumber daya manusia. Salah satu usaha untuk meningkatkan kualitas sumber daya manusia ialah melalui proses pembelajaran di madrasah. Dalam paradigma baru manajemen pendidikan, kepala madrasah sedikitnya harus berfungsi sebagai edukator, manajer, administrator, supervisor, leader, inovator dan motivator yang disingkat EMASLIM (Mulyasa, 2006:9). Kepala madrasah merupakan seorang pemimpin pendidikan yang mempunyai kewenangan untuk mengelola madrasah yang dipimpinnya. Kepala madrasah juga berperan untuk terus memajukan kualitas madrasahnya. Madrasah yang baik dan berkualitas membutuhkan kemampuan kepala madrasah dalam hal mengelola dan mengawasi proses pembelajaran agar berlangsung sesuai dengan tujuan pendidikan yang dicita-citakan.

Kegiatan supervisi (pengawasan) di mana pun jenjang pendidikannya, termasuk di madrasah harus dilakukan oleh seorang atau beberapa orang supervisor (pengawas) yang memiliki kompetensi di bidangnya agar memperoleh kepastian bahwa pekerjaan yang dilaksanakan oleh para pelaksana pendidikan tersebut (guru) selaras dengan tujuan yang telah dirumuskan sebelumnya. Supervisi yang dimaksud dalam artikel ini bukan supervisi yang dilakukan oleh pengawas Pendidikan Islam tetapi supervisi yang dilakukan oleh kepala madrasah. Karena salah satu fungsi manajerial kepala madrasah adalah melakukan supervisi terhadap persiapan, pelaksanaan dan tindak lanjut pembelajaran yang dilaksanakan oleh guru. Supervisi atau pengawasan adalah suatu proses pembimbingan dari pihak atasan kepada guru-guru dan para personalia madrasah lainnya yang langsung menangani belajar para siswa, untuk memperbaiki situasi belajar mengajar, agar para siswa dapat belajar secara efektif dengan prestasi belajar yang semakin meningkat (Pidarta, 1992:5).

Kepala madrasah mempunyai tugas dan tanggung jawab yang besar dalam meningkatkan kualitas madrasah, salah satunya dengan meningkatkan keprofesionalan guru di lingkungan madrasahnya masing-masing. Peningkatan keprofesionalan tersebut merupakan tugas kepala madrasah dalam ranahnya sebagai seorang supervisor akademik. Kegiatan supervisi akademik ini sangat penting untuk dilakukan. Kinerja guru yang sesungguhnya dapat diketahui secara jelas dengan pelaksanaan kegiatan ini. Berangkat dari hal inilah penulis mencoba mengkaji peran dan tujuan kepala madrasah serta bagaimana pelaksanaan supervisi di lembaga pendidikan islam.

\section{METODE}

Jenis penelitian ini menggunakan Library Research atau studi kepustakaan, yang mana proses pengumpulan data dilakukan dan diperoleh melalui kajian kepustakaan. Studi pustaka atau kepustakaan dapat diartikan sebagai serangkaian kegiatan yang berkenaan dengan metode pengumpulan data pustaka, membaca dan mencatat serta mengolah bahan penelitian. Dalam 
penelitian studi pustaka setidaknya ada empat ciri utama yang penulis perlu perhatikan diantaranya: Pertama, bahwa penulis atau peneliti berhadapan langsung dengan teks (nash) atau data angka, bukan dengan pengetahuan langsung dari lapangan. Kedua, data pustaka bersifat "siap pakai" artinya peniliti tidak terjun langsung ke lapangan karena peneliti berhadapan langsung dengan sumber data yang ada di perpustakaan. Ketiga, bahwa data pustaka umumnya adalah sumber sekunder, dalam arti bahwa peneliti memperoleh bahan atau data dari tangan kedua dan bukan data orisinil dari data pertama di lapangan. Keempat, bahwa kondisi data pustaka tidak dibatasi oleh ruang dan waktu. Berdasarkan dengan hal tersebut di atas, eksplorasi terhadap sejumlah data baik data primer maupun sekunder peneliti membaca atau menelaah buku-buku mengenai manajemen kepemimpinan, jurnal, artikel, maupun laporan hasil penelitian terdahulu yang relevan dengan penelitian peneliti serta berkaitan dengan manajemen kepemimpinan pendidikan.

\section{HASIL DAN PEMBAHASAN}

\section{Kepala Madrasah Sebagai Supervisor Pendidikan}

Kepemimpinan merupakan suatu masalah yang komplek dan sulit, karena sifat dasar kepemimpinan itu sendiri memang sangat kompleks. Akan tetapi, perkembangan ilmu saat ini telah membawa banyak kemajuan sehingga pemahaman tentang kepemimpinan menjadi lebih sistematis dan objektif. Kepemimpinan melibatkan hubungan pengaruh yang mendalam yang terjadi di antara orang-orang yang menginginkan perubahan yang signifikan, dan perubahan tersebut mencerminkan tujuan yang dimiliki bersama oleh pemimpin dan pengikutnya (bawahan).

Kepemimpinan dipahami sebagai segala daya upaya bersama untuk menggerakkan semua sumber dan alat (resources) yang tersedia dalam suatu organisasi. Resources tersebut dapat digolongkan menjadi dua bagian besar, yaitu: human resource dan non human resources. Dalam lembaga pendidikan, khususnya lembaga pendidikan Islam yang termasuk salah satu unit organisasi juga terdiri dari berbagai unsur atau sumber, dan manusia merupakan unsur terpenting. Untuk itu dapat dikatakan bahwa sukses tidaknya suatu organisasi untuk mencapai tujuan yang telah ditetapkan sangat tergantung atas kemampuan pemimpinnya untuk menumbuhkan iklim kerja sama dengan mudah dan dapat menggerakkan sumber-sumber daya yang ada sehingga dapat mendayagunakannya dan dapat berjalan secara efektif dan efisien.

Kepala madrasah/madrasah adalah kunci kesuksesan pendidikan di madrasah. Sudarwan Danim, menyebut kepala madrasah/madrasah sebagai the key person-penanggung jawab utama atau faktor kunci untuk membawa madrasah menjadi center of excellence, pusat keunggulan dalam mencetak dan mengembangkan sumber daya manusia (SDM) madrasah. Apakah madrasah itu menjadi efektif, menjadi madrasah yang sukses, atau sebaliknya, semua tergantung dengan peran seorang kepala madrasah (Danim, 2005:96). 
Pengaruh pemimpin itu pada pihak lain dapat memperkembangkan hubungan kemanusiaan yang lebih baik, dapat mempengaruhi pertumbuhan sikap-sikap yang positif dari pada individuindividu yang dipimpinnya. Tetapi yang paling penting ialah pengaruh kepemimpinannya sangat menentukan bagaimana kualitas kegiatan kerjasama dan kualitas hasil yang dapat dicapai oleh kegiatan kerjasama dalam lembaga.

Secara operasional, kepala madrasah adalah orang yang paling bertanggung jawab dalam mengkoordinasikan, menggerakkan dan menyelaraskan semua sumber daya (resources) madrasah yang dipimpinnya. Kepemimpinan kepala madrasah merupakan faktor pendorong untuk mewujudkan visi, misi, tujuan dan sasaran madrasah yang dipimpinnya menuju madrasah yang bermutu dan berkualitas. Bermutu dalam bidang pelayanan publik, di bidang pembelajaran, sarana prasarana, pengembangan SDM, baik di bidang prestasi akademik maupun non akademik. Jadi sebagai kepala madrasah merupakan tugas utama dan mulia karena di dalamnya ada tugas suci untuk menjadikan manusia yang bermutu/berkualitas, baik dari sisi fisik maupun non fisik. Menciptakan madrasah yang bermutu, melahirkan generasi yang berkualitas, mencetak generasi yang mumpuni merupakan tugas suci lain dari seorang kepala madrasah.

Untuk memungkinkan tercapainya tujuan pendidikan di madrasah, kepala madrasah bukan hanya melakukan fungsi sebagai manajer dan leader saja tetapi ada peran-peran lainnya yang harus dijalani dan melekat dengan kepala madrasah dalam tugas operasional sehari-hari. Mulyasa menuliskan tujuh peran kepala madrasah yang harus di amalkan dalam bentuk tindakan nyata di madrasah/madrasah yang disingkat dengan 'EMASLIM', yaitu peran sebagai Educator, Manager, Administrator, Supervisor, Leader, Innovator, and Motivator (Mulyasa, 2004:97).

Tugas kepala madrasah sebagai supervisor yaitu mensupervisi kinerja guru. Kinerja guru disini berkaitan dengan proses pembelajaran di kelas karena kegiatan utama di madrasah tidak terlepas dari proses pembelajaran kepada peserta didik. Kegiatan pengawasan dalam proses pembelajaran tersebut dikenal dengan istilah supervisi akademik.

Supervisi adalah suatu usaha menstimulir, mengkoordinir, dan membimbing secara kontinu pertumbuhan guru-guru madrasah baik secara individual maupun secara kolektif, agar lebih mengerti dan lebih efektif dalam mewujudkan seluruh fungsi pengajaran, sehingga dengan demikian mereka mampu dan lebih cakap berpartisipasi dalam masyarakat demokrasi modern (Daryanto, 2008:170). Supervisi adalah segala bantuan dari supervisor untuk memperbaiki manajemen pengelolaan madrasah dan meningkatkan kinerja staf/guru dalam menjalankan tugas, fungsi, dan kewajibannya sehingga tujuan pendidikan dapat dicapai dengan optimal (Jasmani \& Mustofa, 2013:27).

Kinerja guru yang mengarah pada kegiatan akademik yaitu proses pembelajaran menjadi poin penting dalam keberhasilan pendidikan di suatu madrasah. Oleh karena itu, pelaksanaan supervisi akademik sebagai suatu kegiatan pengawasan diharapkan dapat berjalan sesuai dengan 
tujuannya. Pelaksanaan supervisi di madrasah-madrasah pada awalnya hanya fokus pada supervisi administrasi saja. Supervisi yang memfokuskan pada administrasi guru saja tidak cukup untuk menggambarkan kondisi kinerja guru yang sebenarnya. Kondisi kinerja guru yang sebenarnya hanya dapat diketahui secara nyata dan jelas jika dilakukan suatu pengawasan dan kontrol oleh seorang pengawas yang berkompeten dan berpengalaman yaitu dengan kegiatan supervisi akademik.

Konsep kepala madrasah sebagai supervisor akademik adalah dengan memberikan bantuan, bimbingan, dan arahan terhadap para guru dalam menghadapi permasalahanpermasalahan yang dihadapi. Selain itu, perbaikan-perbaikan yang diberikan oleh supervisor terhadap guru dilakukan agar pembelajaran dapat berjalan dengan baik sehingga diharapkan kualitas pembelajaran di madrasah juga meningkat. Selain itu, tujuan dari kegiatan supervisi akademik adalah untuk meningkatkan kinerja dan kemampuan keprofesionalan guru (Sagala, 2012:94).

Kinerja guru dalam proses pembelajaran menjadi titik fokus utama dalam pelaksanaan supervisi akademik yaitu dalam melaksanakan tanggung jawabnya sebagai tenaga profesional yang dimanifestasikan dalam kinerja membelajarkan peserta didiknya (Suhardan, 2010:48). Menurut Glikman, menyatakan bahwa: "Supervisi pengajaran adalah serangkaian kegiatan membantu guru mengembangkan kemampuannya mengelola proses belajar mengajar demi pencapaian tujuan pengajaran (Faturrohman \& Suryana, 2011:30). Adapun yang dimaksud dengan supervisi akademik yaitu supervisi yang menitikberatkan pengamatan pada masalah akademik, yaitu hal-hal yang berada dalam lingkup kegiatan pembelajaran yang dilakukan oleh guru untuk membantu siswa ketika sedang dalam proses belajar (Arikunto, 2006:5).

Kualitas kinerja guru yang berfokus pada kompetensi profesional meliputi 2 aspek, yaitu: (1) penguasaan materi, struktur, konsep, dan pola pikir keilmuan yang mendukung mata pelajaran yang diampu, dan (2) mengembangkan keprofesionalan melalui tindakan reflektif (Pedoman Pelaksanaan Penilaian Kerja Guru, 2010:42).

Ada dua strategi penting yang dapat dilakukan untuk meningkatkan kinerja guru, yaitu pelatihan dan motivasi kinerja. Pelatihan digunakan untuk menanggulangi rendahnya kemampuan guru. Program pelatihan harus efektif sehingga dapat meningkatkan kinerja guru. Sedangkan motivasi kinerja digunakan untuk menanggulangi rendahnya semangat dan gairah kerja (Barnawi \& Arifin, 2012:80).

Kesimpulan dari pendapat para ahli, bahwasannya kegiatan supervisi merupakan usaha yang dilakukan kepala madrasah dalam membimbing maupun mengkoordinir para guru secara kontinu secara individual maupun secara kolektif, agar lebih mengerti dan lebih efektif dalam mewujudkan seluruh fungsi pengajaran, sehingga dengan demikian mereka mampu dan lebih cakap berpartisipasi dalam masyarakat demokrasi modern. Hasil supervisi yang didapat akan memberikan 
gambaran tentang kinerja guru dan bantuan apa yang semestinya diberikan oleh seorang supervisor kepada guru yang disupervisi. Hasil tersebut juga akan memberikan penjelasan tentang apa saja hal-hal yang dapat mempengaruhi kinerja guru. Peningkatan kinerja guru dalam hal keprofesionalannya tentunya juga tidak terlepas dari kualifikasi akademik yang dimiliki, kesesuaian mata pelajaran dengan program studi pendidikan terakhirnya, dan sudah atau belum bersertifikat guru.

\section{Peran Kepala Madrasah Sebagai Supervisor}

Supervisi sebagai salah satu fungsi pokok dalam administrasi pendidikan, bukan hanya tugas para pengawas, tetapi juga tugas kepala madrasah terhadap guru-guru dan pegawai-pegawai di madrasah (Suryosubroto, 1994:19). Adiministrasi dan supervisi merupakan alat penunjang untuk mencapai tujuan pendidikan. Demikian juga halnya tujuan pendidikan di madrasah dapat tercapai bila di dalamnya ada kegiatan administrasi dan supervisi secara sistematis dan kontinu. Kegiatan supervisi di madrasah di laksanakan secara menyeluruh, meliputi hal-hal yang berhubungan dengan kurikulum, murid, sarana, prasarana, dan hubungan madrasah dengan masyarakat.

Peraturan Menteri Pendidikan Nasional Nomor 13 Tahun 2007, salah satunya adalah kompetensi supervisi kepala madrasah yang meliputi: (1) merencanakan program supervisi akademik dalam rangka peningkatan profesionalisme guru, (2) melaksanakan supervisi akademik terhadap guru dengan menggunakan pendekatan dan teknik supervisi yang tepat, dan (3) menindaklanjuti hasil supervisi akademik terhadap guru dalam rangka peningkatan profesionalisme guru (Peraturan Menteri Pendidikan Nasional, 2007:8).

Berdasarkan Permendiknas di atas, menunjukkan bahwa tanggung jawab kepala madrasah sebagai supervisor dalam kegiatan supervisi akademik meliputi perencanaan, pelaksanaan, dan evaluasi serta tindak lanjut. Kegiatan supervisi akademik dilakukan untuk meningkatkan kualitas keprofesionalan guru dan kegiatan untuk meningkatkan kinerja guru di madrasah yaitu dalam proses pembelajaran terhadap peserta didik di kelas.

Senada dengan penjelasan di atas, Siti Muslimah juga menjelaskan bahwa tujuan kegiatan supervisi akademik hakikatnya adalah untuk melihat bagaimana dan sejauh mana kualitas guru dalam mengajar dan bagaimana penyampaian guru tersebut apakah diterima oleh peserta didik atau tidak, dengan kata lain gambaran kinerja guru saat mengajar di kelas.

Binti Maunah mengemukakan bahwa seorang kepala madrasah berperan sebagai supervisor yang di dalamnya meliputi (Maunah, 2009:37):

1. Koordinator

Seorang kepala madrasah dapat mengkoordinasikan program belajar mengajar, tugas-tugas anggota staf berbagai kegiatan yang berbeda-beda di antara guru-guru. Contoh kongkret mata pelajaran yang dibina oleh berbagai guru. 


\section{Konsultan}

Seorang kepala madrasah dapat member bantuan bersama mengkonsultasikan masalah yang dialamai guru baik secara individual maupun secara kelompok. Misalnya; kesulitan dalam mengatasi anak yang sulit belajar, yang menyebabkan guru sendiri sulit mengatasi dalam tatap muka di kelas.

3. Pemimpin kelompok

Sebagai pemimpin kelompok seorang kepala madrasah harus dapat memimpin sejumlah staf guru dalam mengembangkan potensi kelompok, pada saat pengembangan kurikulum, materi pelajaran dan kebutuhan professional guru-guru secara bersama. Sebagai pemimpin kelompok ia dapat mengembangkan ketrampilan dan kiat-kiat dalam bekerja untuk kelompok (working with the group) dan bekerja melalui kelompok (working through the group).

4. Evaluator

Sebagai evaluator seorang kepala madrasah dapat membantu guru-guru dalam menilai hasil dan proses belajar, dapat menilai kurikulum yang sedang dikembangkan. Ia juga belajar menatap dirinya sendiri. Ia dibantu dalam merefleksi dirinya, yaitu konsep dirinya (self concept), ide/cita-cita dirinya (self idea), realitas dirinya (self reality).

Sebagai supervisor, kepala madrasah berfungsi sebagai sosok pribadi yang secara kontinu memberikan bimbingan, bantuan, pengawasan, dan penilaian terhadap masalah-masalah yang berhubungan dengan pengembangan dan perbaikan program kegiatan pengajaran dan pendidikan. Kepala madrasah harus memberikan layanan yang optimal kepada seluruh pelaksana pendidikan, khususnya pelayanan bagi guru yang secara profesional bertanggung jawab langsung terhadap proses belajar mengajar di madrasah (Barizi, 2011:169).

Menurut Ngalim Purwanto, tugas dari kepala madrasah sebagai supervisor adalah sebagai berikut (Purwanto, 2009:119):

1. Membangkitkan dan merangsang guru-guru dan pegawai madrasah di dalam menjalankan tugasnya masing-masing dengan sebaik-baiknya.

2. Berusaha dan melengkapi alat-alat perlengkapan madrasah termasuk media intruksional yang diperlukan bagi kelancaran dan keberhasilan proses belajar-mengajar.

3. Bersama guru-guru berusaha mengembangkan, mencari, dan menggunakan metode-metode mengajar yang lebih sesuai dengan tuntutan kurikulum yang sedang berlaku.

4. Membina kerjasama yang baik harmonis di antara guru-guru dan pegawai madrasah lainnya.

5. Berusaha mempertinggi mutu dan pengetahuan guru-guru dan pegawai madrasah, antara lain mengadakan diskusi-diskusi kelompok, menyediakan perpustakaan madrasah, dan mengirim mereka untuk mengikuti penataranpenataran, seminar sesuai dengan bidangnya masing masing. 
6. Membina hubungan kerjasama antara madrasah dengan BP3 dan instansiinstansi lain dalam rangka peningkatan mutu pendidikan para siswa.

Peran kepala madrasah sebagai supervisor sekurang-kurangnya ada dua tugas yang harus dilaksanakan (Barizi, 2011:170).:

Pertama, mengendali program in-service dengan kewibawaan dan semangat kepemimpinan. Kepala madrasah di sini disarankan mampu memberikan layanan kepada semua bawahan secara akomodatif dalam suasana keakraban dengan tanpa mengurangi kewibawaan dan semangat kerja yang diinginkan. Kepala madrasah harus mampu meretas semua persoalan kependidikan yang muncul dengan adil dan bijaksana. Kepala madrasah tidak diperkenankan melakukan deskriminasi layanan kepada semua sivitas madrasah.

Kedua, membantu guru baru dalam menemukan dirinya untuk melaksanakan tugas keguruan. Di sini kepala madrasah harus bisa melaksanakan supervisi kepada semua guru mata pelajaran, sehingga kepala madrasah adalah seorang aktor yang seakan-akan piawai di dalam penguasaan bidang pelajaran. Misalnya kepala madrasah yang secara profesional dari lulusan fakultas agama, bagaimana pun secara umum harus mampu memahami kerangka ilmu eksakta seperti Matematika, IPA, Seni, dan sebagainya. Sehingga supervisi kepada guru-guru yang bersangkutan bisa dilakukan dengan baik.

Secara umum peran yang harus dilakukan kepala madrasah yang utama berusaha terus memperbaiki kualitas pendidikan di lembaga yang di pimpinnya. Kemudian kepala madrasah harus mempunyai ketrampilan dalam berkomunikasi membina kerjasama antara guru dan kerja sama dengan mitra pendidikan yang lain. Kepala madrasah dalam mensupervisi (pengawasan) terhadap guru-guru harus bisa mencari kesalahan, kemudian memberikan penyelesaian dan bisa memberikan motivasi kepada guru agar dala menjalankan tugasnya dapat dilaksanakan dengan baik.

\section{Tujuan Diadakan Supervisi Oleh Kepala Madrasah}

Supervisi bertujuan mengembangkan iklim yang kondusif dan lebih baik dalam kegiatan belajar-mengajar, melalui pembinaan dan peningkatan profesi mengajar. Dengan kata lain, tujuan supervisi adalah membantu dan memberikan kemudahan kepada para guru untuk belajar meningkatkan kemampuan guna mewujudkan tujuan belajar peserta didik (Mulyasa, 2013:241).

Secara operasional dapat dikemukakan beberapa tujuan konkrit dari supervisi pendidikan (Sahertian, 1981:24):

1. Membantu guru melihat dengan jelas tujuan-tujuan pendidikan.

2. Membantu guru dalam membimbing pengalaman belajar peserta didik.

3. Membantu guru dalam menggunakan sumber-sumber pengalaman belajar.

4. Membantu guru dalam menggunakan metode dan media pembelajaran modern.

5. Membantu guru dalam memenuhi kebutuhan belajar peserta didik. 
6. Membantu guru dalam mengevaluasi kemajuan peserta didik dan hasil pekerjaan guru itu sendiri.

7. Membantu guru dalam membina reaksi mental atau moral kerja guru dalam rangka pertumbuhan pribadi dan jabatan mereka.

8. Membantu guru baru di madrasah sehingga mereka merasa gembira dengan tugas yang diperolehnya.

9. Membantu guru agar lebih mudah mengadakan penyesuaian terhadap masyarakat.

10. Membantu guru agar waktu dan tenaga tercurahkan sepenuhnya dalam pembinaan madrasahnya.

Dari seluruh tujuan yang di diharapkan kepala madrasah dapat melaksanakan dengan baik, pada intinya kepala madrasah harus dapat memfasilitasi para guru, apapun yang di dibutuhkan guru kepala sekolah harus bisa menjadi solusi.

\section{Pelaksanaan Supervisi Oleh Kepala Madrasah}

Sebagaimana diatur dalam Peraturan Mentri Pendidikan Nasional No. 13 tahun 2007 tentang Standar Kepala Madrasah/Madrasah. Salah satu kompetensi yang harus dijalankan oleh kepala madrasah dalam hal kompetensi supervisi adalah membina para guru dalam pengelolaan dan administrasi kelas berdasarkan manajemen peningkatan-peningkatan mutu pendidikan di madrasah. Kepala madrasah selaku supervisor pendidikan memiliki fungsi mengarahkan, membimbing dan mengawasi seluruh kegiatan pendidikan dan kegiatan pembelajaran yang dilaksanakan guru.

Teknik yang digunakan dalam melaksanakan supervisi oleh kepala madrasah terhadap guru-guru dan pegawai madrasah dapat dilakukan dengan teknik perseorangan dan teknik kelompok. Kegiatan yang termasuk teknik perseorangan adalah mengadakan kunjungan kelas, kunjungan observasi, membimbing guru-guru tentang cara-cara mempelajari pribadi siswa dan atau mengatasi problema yang dialami siswa, dan membimbing guru-guru dalam hal yang berhubungan dengan pelaksanaan kurikulum madrasah. Sedangkan yang termasuk teknik kelompok adalah mengadakan pertemuan atau rapat dengan guru-guru untuk membicarakan berbagai hal yang berhubungan dengan proses dan hasil belajar mengajar, mengadakan dan membimbing diskusi kelompok di antara guru-guru bidang studi, memberikan kesempatan kepada guru-guru untuk mengikuti penataran yang sesuai dengan bidang tugasnya, dan membimbing guru-guru dalam mempraktekkan hasil-hasil penataran yang telah diikutinya (Purwanto, 2009:121).

Supervisi perlu disusun oleh kepala madrasah dan disosialisasikan kepada guru melalui rapat madrasah, sehingga guru-guru mengetahui dan memahami maksud dan tujuan dari program supervisi tersebut. Dalam menyusun program supervisi akademik, kepala madrasah juga dapat melibatkan guru-guru terutama sekali dalam menentukan jadwal supervisi. Dengan demikian, guru ikut berpartisipasi dalam kegiatan tersebut dan turut bertanggung jawab atas pelaksanaannya. 
Kemudian pada sisi lain guru dapat mengetahui dan memahami supervisi akademik yang dilakukan sejak dini, sehingga sudah dapat mempersiapkan diri untuk melengkapi administrasi kelas maupun adminintrasi pembelajaran dan perangkat-perangkat lainnya. Dengan adanya kebersamaan dalam menyusun suatu program, maka semua pihak akan merasa dihargai dan dapat menghilangkan kesalahpahaman antara kepala madrasah dengan guru. Untuk itu sangat perlu disusun dan disosialisasikan program supervisi sebagai pembinaan awal terhadap guru-guru yaitu menyampaikan atau menjelaskan tentang pengertian, tujuan dan manfaat dari supervisi akademik.

Setelah menyusun perencanaan program supervisi akademik, maka selanjutnya memasuki tahap pelaksanaannya. Pelaksanaan akan berjalan baik bila segala rencana yang telah disusun sudah dipersiapkan dengan baik. Sasaran kegiatan supervisi akademik intinya adalah untuk mengembangkan dan meningkatkan proses pembelajaran yang di dalamnya terdiri dari sistem pembelajaran, metode pembelajaran, media/alat pembelajaran, penyusunan perangkat pembelajaran berupa silabus dan RPP, dan evaluasi hasil pembelajaran. Dengan demikian berarti esensi supervisi akademik itu sama sekali bukan menilai unjuk kerja guru dalam mengelola proses pembelajaran, melainkan membantu guru mengembangkan dan meningkatkan kompetensi pedagogik serta profesional-ismenya dalam proses belajar mengajar didalam dunia pendidikan.

Tindak lanjut supervisi akademik dilakukan dengan cara mengevaluasi secara umum kepada seluruh guru-guru dalam setiap rapat tahunan, bulanan dan mingguan. Setelah kepala madrasah memperoleh hasil dari apa yang menjadi penilaian supervisi akademik dengan melakukan penilaian terhadap bahan ajar dan kunjungan kelas, dalam program mingguan ada evaluasi berupa briefing yang dilakukan setiap hari Senin. Di dalam forum tersebut dijelaskan hasil dari tim supervisor tetapi tidak secara personal melainkan disebutkan kesalahan-kesalahan sehingga semua guru mampu mengevaluasi dirinya masing-masing.

Evaluasi supervisi kelompok dapat dilakukan kepala madrasah pada rapat rutin bulanan, semester dan tahun baik di awal maupun di akhir tahun ajaran baru. Evaluasi melalui rapat rutin guru ini seperti yang dilakukan oleh kepala madrasah dengan memberikan motivasi, bimbingan dan arahan kepada guru dan karyawan. Dan pertemuan rutin guru ini adalah sebagai bentuk evaluasi dan supervisi akademik kepala madrasah dalam menilai dan meningkatkan kompetensi pedagogik dan kinerja guru agar lebih profesional sehingga mutu pembelajaran meningkat sesuai harapan. Dalam pelaksanaan evaluasi ini merupakan solusi yang ditempuh kepala madrasah sebagai supervisor dalam mencari persepsi kesamaan dan pembinaan terhadap guru yang dilakukan secara berkelompok yaitu dengan cara mengadakan rapat rutinan.

Tindak lanjut dari supervisi akademik yang dilakukan kepala madrasah dan tim supervisor dilakukan dengan cara mengevaluasi guru-guru secara personal melalui pemanggilan ke ruang kepala madrasah dan secara berkelompok melalui rapat rutin. Dalam pelaksanaan evaluasi, akan disampaikan kekurangan setiap proses pembelajaran serta menjelaskan apa yang harus diperbaiki. 
Setelah dilaksanakan tahap tersebut, kepala madrasah melalui wakilnya melakukan pengontrolan setiap hari dengan cara mendatangi kelas-kelas untuk mengecek kehadiran guru-guru setiap kelasnya dan dilakukan sehari 3x yaitu setiap pagi, setelah istirahat dan selesai melaksanakan shalat Dhuhur. Hal ini dilakukan untuk mengoptimalkan proses pembelajaran, sehingga proses pembelajaran yang diharapkan dapat tercapai Evaluasi pelaksanaan supervisi memberikan manfaat bagi kepala madrasah dan guru. Kepala madrasah dapat mengetahui sejauh mana target yang sudah dicapai dalam pelaksanaan peningkatan kemampuannya. Guru juga diharapkan dapat menerima hasil evaluasi secara terbuka, dan menerima saran serta arahan dari kepala madrasah atau supervisor untuk perbaikannya.

\section{KESIMPULAN DAN SARAN}

1. Konsep kepala madrasah sebagai supervisor akademik adalah dengan memberikan bantuan, bimbingan, dan arahan terhadap para guru dalam menghadapi permasalahan-permasalahan yang dihadapi. Selain itu, perbaikan-perbaikan yang diberikan oleh supervisor terhadap guru dilakukan agar pembelajaran dapat berjalan dengan baik sehingga diharapkan kualitas pembelajaran di madrasah juga meningkat. Selain itu, tujuan dari kegiatan supervisi akademik adalah untuk meningkatkan kinerja dan kemampuan keprofesionalan guru.

2. Peran Kepala Madrasah sebagai supervisor tercantum pada Peraturan Menteri Pendidikan Nasional Nomor 13 Tahun 2007, salah satunya adalah kompetensi supervisi kepala madrasah yang meliputi: (1) merencanakan program supervisi akademik dalam rangka peningkatan profesionalisme guru, (2) melaksanakan supervisi akademik terhadap guru dengan menggunakan pendekatan dan teknik supervisi yang tepat, dan (3) menindaklanjuti hasil supervisi akademik terhadap guru dalam rangka peningkatan profesionalisme guru.

3. Supervisi bertujuan mengembangkan iklim yang kondusif dan lebih baik dalam kegiatan belajar-mengajar, melalui pembinaan dan peningkatan profesi mengajar. Dengan kata lain, tujuan supervisi adalah membantu dan memberikan kemudahan kepada para guru untuk belajar meningkatkan kemampuan guna mewujudkan tujuan belajar peserta didik.

4. Teknik yang digunakan dalam melaksanakan supervisi oleh kepala madrasah terhadap guruguru dan pegawai madrasah dapat dilakukan dengan teknik perseorangan dan teknik kelompok. Kegiatan yang termasuk teknik perseorangan adalah mengadakan kunjungan kelas, kunjungan observasi, membimbing guru-guru tentang cara-cara mempelajari pribadi siswa dan atau mengatasi problema yang dialami siswa, dan membimbing guru-guru dalam hal yang berhubungan dengan pelaksanaan kurikulum madrasah. Sedangkan yang termasuk teknik kelompok adalah mengadakan pertemuan atau rapat dengan guru-guru untuk membicarakan berbagai hal yang berhubungan dengan proses dan hasil belajar mengajar, mengadakan dan membimbing diskusi kelompok di antara guru-guru bidang studi, memberikan kesempatan 
kepada guru-guru untuk mengikuti penataran yang sesuai dengan bidang tugasnya, dan membimbing guru-guru dalam mempraktekkan hasil-hasil penataran yang telah diikutinya.

\section{DAFTAR PUSTAKA}

AA, Pupuh Fathurrohman and Suryana, (2011) Supervisi Pendidikan Dalam Pengembangan Proses Pembelajaran. Bandung: PT Refika Aditama.

Arikunto, Suharsimi. (2006). Dasar-Dasar Supervisi. Jakarta: PT Rineka Cipta.

Asf, Jasmani \& Syaiful Mustofa. (2013). Supervisi Pendidikan: Terobosan Baru dalam Peningkatan Kinerja Pengawas Madrasah dan Guru. Jogjakarta: Ar-Ruzz Media.

Barizi, Ahmad. (2011). Pendidikan Integratif: Akar Tradisi \& Integrasi Keilmuan Pendidikan Islam. Malang: UIN-Maliki Press.

Barnawi and Mohammad Arifin. (2012). Kinerja Guru Profesional. Yogyakarta: Ar-Ruzz Media.

Danim, Sudarwan. (2005). Visi Baru Manajemen. Jakarta: Bumi Aksara.

Daryanto, H. M. (2008). Administrasi Pendidikan. Jakarta: PT. Rineka Cipta.

Maunah, Binti. (2009). Supervisi Pendidikan Islam. Yogyakarta: TERAS.

Mulyasa, E. (2013). Manajemen dan Kepemimpinan Kepala Madrasah. Jakarta: Bumi Aksara.

Mulyasa, E. (2006). Menjadi Kepala Madrasah Profesional. Jakarta: Rosda.

Mulyasa, E. (2004). Manajemen Berbasis Madrasah Konsep, Strategi dan Implementasi. Bandung: Remaja Rosda Karya.

Pedoman Pelaksanaan Penilaian Kinerja Guru (PK Guru) Pembinaan Dan Pengembangan Profesi Guru Buku 2, (2010). Kementerian Pendidikan Nasional: Direktorat Jenderal Peningkatan Mutu Guru Dan Tenaga Keguruan".

Peraturan Menteri Pendidikan Nasional Nomor 13 Tahun 2007 Tentang Standar Kepala Madrasah/Madrasah.

Pidarta, Made. (1992). Pemikiran Tentang Supervisi Pendidikan. Jakarta : Bumi Aksara.

Purwanto, M. Ngalim. (2009) Administrasi dan Supervisi Pendidikan. Bandung: PT Remaja Rosdakarya.

Sagala, Syaiful. (2012). Supervisi Pembelajaran Dalam Profesi Pendidikan. Bandung: Alfabeta..

Sahertian, Piet A. (1981). Prinsip \& Teknik Supervisi Pendidikan. Surabaya: Usaha Nasional.

Suhardan, Dadang. (2010). Supervisi Profesional Layanan Dalam Meningkatkan Mutu Pembelajaran Di Era Otonomi Daerah. Bandung: Alfabeta.

Suryosubroto, (1994). Dimensi-Dimensi Administrasi Pendidikan di Madrasah. Jakarta: Bina Aksara. 